\title{
Climate change beliefs and forest management in eastern Oregon: implications for individual adaptive capacity
}

\author{
$\underline{\text { Angela E. Boag }}^{1}, \underline{\text { Joel Hartter }}^{1,2}, \underline{\text { Lawrence C. Hamilton }}^{2,3}$, Nils D. Christoffersen $^{4}$, Forrest R. Stevens $^{5}{ }^{\text {Michael }^{\text {W. Palace }}}{ }^{6,7}$
} and Mark J. Ducey ${ }^{2,8}$

\begin{abstract}
The management decisions of private landowners affect forest structure and composition, and may impact the resilience of forested regions. In this case study we assessed barriers to both intentional and incidental climate-adaptive forest management among nonindustrial private forest owners in eastern Oregon, USA. In this context, incidental adaptations result from synergies between climate-adaptive forest management and actions motivated by goals such as wildfire mitigation, which landowners may prioritize regardless of concerns about climate change. Through semistructured interviews we used qualitative analyses to identify barriers to adaptation, including subjective (cognitive and experiential) and structural barriers (social, political, and economic) by comparing individual cases. Overall, we found that intentional climate change adaptation had low salience among participants, though a large majority of forest owners were active managers motivated by other goals, contributing to widespread incidental adaptation. We found that nonindustrial private forest owners who engaged in or considered intentional climate adaptation actions generally believed that anthropogenic climate change is occurring. Many respondents perceived local environmental change, notably reduced snowpack, but this was not associated with adaptive actions or intentions. The few participants who considered or implemented intentional climate adaptation actions generally had written forest management plans containing both forest inventories and specific management goals. Improving access to resources for forest management planning may enhance fire- and climate-smart forest management by facilitating scenario visioning and formalizing intentions. Although climate change beliefs were subjective barriers to intentional climate adaptation, many of the same structural barriers limited intentional and incidental adaptation. Place-based education, reliable funding mechanisms, and cooperative approaches among landowners may enhance adaptive capacity and promote the resilience of these nonindustrial private forestlands.
\end{abstract}

Key Words: adaptive capacity; climate change; climate change adaptation; drought; forest management; private land; resilience

\section{INTRODUCTION}

As climate change adaptation theory develops there is growing interest in understanding the conditions that provide opportunities for and barriers to adaptation among institutions and individuals (Moser and Ekstrom 2010, Biesbroek et al. 2013, Klein et al. 2014, Eisenack et al. 2014). Adaptation is the process of adjustment to actual or expected climate and its effects that may or may not moderate harm or exploit beneficial opportunities (modified from Agard et al. 2014). Adaptation actions can take various forms. They include technological projects or social reforms that reduce the exposure and sensitivity of ecosystems and communities to climate variation and increase their adaptive capacity (Leichenko and O'Brien 2006). An individual's adaptive capacity describes their ability to respond successfully to climate variability and change based on adjustments to behavior, resources, and technologies (modified from Adger et al. 2007). Barriers to adaptation are impediments to specific adaptation actions that can be reduced or overcome (modified from Eisenack et al. 2014). Evidence indicates that individual landowners are beginning to consider climate change adaptation actions in forestry in North America and Europe, with self-reported rates of implementation varying from very low to moderate (Keskitalo et al. 2011, Blennow 2012, van Gameren and Zaccai 2015, Bissonnette et al. 2017, Vulturius et al. 2018). Forest management decisions have decadal and centennial-scale repercussions for forest landscapes, enhancing the importance of understanding opportunities for and barriers to climate-adaptive forest management (Lawrence and Gillett 2011, Schoene and Bernier 2012, van Gameren and Zaccai 2015).

Factors promoting or constraining individual adaptation can generally be characterized as subjective barriers resulting from cognitive and experiential processes, or structural barriers arising from broader economic, social, or political conditions (Grothmann and Patt 2005, Smit and Wandel 2006, Vulturius et al. 2018). Subjective barriers include beliefs about the existence of anthropogenic climate change and its effects (Blennow 2012), which may be conditioned by cultural orientation (Kahan et al. 2011). Climate change beliefs in turn influence individual local or global concern about climate change and relative perception of risk (Slovic et al. 2007, van der Linden 2015). Relative risk perception is the perceived probability of being exposed to climate change impacts and an appraisal of how harmful those impacts will be to things the individual values (Grothmann and Patt 2005, van der Linden 2015). Immediacy of harm is also an issue; most individuals respond to concerns that are immediately and personally relevant (Paton et al. 2001, Moser and Dilling 2004, Adger et al. 2009). An individual's perception of their own ability

\footnotetext{
${ }^{1}$ Environmental Studies Program, University of Colorado Boulder, ${ }^{2}$ Carsey School of Public Policy, University of New Hampshire, ${ }^{3}$ Sociology Department, University of New Hampshire, ${ }^{4}$ Wallowa Resources, Enterprise, Oregon, ${ }^{5}$ Department of Geography and Geosciences, University of Louisville, ${ }^{6}$ Institute for the Study of Earth, Oceans and Space, University of New Hampshire, ${ }^{7}$ Department of Earth Sciences, University of New Hampshire, ${ }^{8}$ Department of Natural Resources and the Environment, University of New Hampshire
} 
to adapt, which may or may not match their objective capacity, may also form a barrier to adaptation (Grothmann and Patt 2005, Tompkins and Eakin 2012). Finally, experiential factors, including experiencing or perceiving extreme weather events, may influence risk perceptions and levels of concern, contributing to action or inaction (Amundsen et al. 2010, Blennow 2012, Akerlof et al. 2013).

Structural barriers to climate change adaptation include the political, social, environmental, and economic constraints on individual adaptation decision making and implementation (Smit and Wandel 2006, Moser and Ekstrom 2010, Eisenack and Stecker 2012, Biesbroek et al. 2013, Klein et al. 2014). Individuals may lack the financial, social, or political capital to perform climate-adaptive management actions. Individuals may also find themselves in broader institutional or governance contexts with inadequate leadership, communication, or information (Moser and Ekstrom 2010, Biesbroek et al. 2013). The importance of subjective versus structural barriers to adaptation depends on context, and a key priority in adaptation research is understanding which barriers arise in certain contexts in order to inform interventions (Wise et al. 2014).

In the developing literature on climate change adaptation by individual private forest owners, studies diverge on the relative importance of structural versus subjective barriers to adaptation. Forest management also highlights the synergies and differences between current adaptive strategies to address existing risks, including insects, disease, wildfire and storms, and adaptation options to enhance resilience to climate change. We aim to explicitly consider individual adaptive capacity in both contexts.

\section{Climate change adaptation by individual forest owners}

Climate change is altering forest ecosystems globally. Rising temperatures and shifting moisture regimes are gradually shifting growing conditions for tree species, while climate-mediated changes in the frequency, size, and intensity of disturbances will continue to alter forest structure and function in decades to come (Turner 2010, Vose et al. 2012, Enright et al. 2015). Climatemediated forest disturbances such as wildfires, insects, and disease outbreaks ignore property boundaries and spread across both public and private lands. In the U.S. and Europe over $50 \%$ of forested lands are privately owned (both nonindustrial and industrial), and therefore private management responses to climate change may impact the social-ecological resilience of forested regions (UNECE FAO 2010, Tompkins and Eakin 2012, Ruseva and Fischer 2013, Butler et al. 2016).

Nonindustrial private forest owners (hereafter forest owners), also known as family forest owners, control $36 \%$ of forested lands in the U.S. and typically own smaller tracts of forest compared to large commercial (or industrial) timber estates (Butler et al. 2016). In the western U.S., these nonindustrial private lands are often at low elevations near towns and rural communities (Latta et al. 2010), and are thus the "front lines" for buffering communities from climate change-related natural hazards, including increasingly frequent large wildfires (Westerling 2016, Abatzoglou and Williams 2016). Nonindustrial private lands often border federal or state lands, creating a mixed-ownership landscape in which their management practices affect the continuity of fuels, and therefore wildfire, between public lands and communities (Ager et al. 2012, Fischer and Charnley 2012).
Many studies assess the motivations behind private landowner wildfire mitigation actions such as fuels management (reviewed by McCaffrey et al. 2012). The rich literature on barriers to fuels management and prescribed burning indicates that management preferences do not appear to be influenced by demographic characteristics; decisions to implement wildfire mitigation actions are influenced by social context, trade-offs with other amenity values, perceived efficacy of activities, and personal capacity to implement management actions (McCaffrey et al. 2012). People who perceive greater social capital in their community are also more likely to take action on their properties to reduce wildfire risk (Agrawal and Monroe 2006). Additionally, in a study conducted in central Oregon researchers found that landowners' perceptions of wildfire risk and propensity to conduct fuel treatments correlated with hazardous fuel conditions near their land, whether they have a home at risk, prior experience with wildfire, financial capacity to conduct treatments, and membership in land stewardship organizations (Fischer et al. 2014). These drivers of and barriers to fire-smart forest management echo those identified in the climate adaptation literature (Spies et al. 2010). Indeed, most studies identifying barriers to climate adaptation identify barriers that are not climate change-specific, but rather represent existing challenges in natural resources management (Biesbroek et al. 2013)

Climate change adaptation within the context of forest management can include intentional and anticipatory climate change-specific responses such as planting tree species that will be better adapted to a future climate (Yousefpour et al. 2017), or managing forest density and composition outside of the historic range of variation (Keenan 2015, Nagel et al. 2017). Responses can also be reactive "wait-and-see" approaches to cope with nascent threats, such as cutting trees that appear water-stressed (Beck 1992, Yousefpour et al. 2017). Some responses can be both anticipatory and reactive, such as thinning stands to improve water capture, storage, and flow (Grant et al. 2013). Thinning may mitigate both current and future drought stress, wildfire spread, and disease and insect outbreaks, all of which may increase under climate change in certain regions (Chmura et al. 2011, van Gameren and Zaccai 2015). Thinning may therefore represent a "no-regrets" or "win-win" adaptation option (Carter 1996), addressing both current and future risks. Similar actions include creating defensible spacing, underbrush clearing, and using prescribed burns to return historic fire regimes to ecosystems (Clark et al. 2016).

Adaptation may therefore be incidental if landowners carry out such actions for reasons not primarily related to climate change. We use the term "incidental" as opposed to "accidental," as used elsewhere (van Gameren and Zaccai 2015), because we feel that "accidental adaptation" suggests a complete lack of awareness of climate change. In reality, the importance of climate change in motivating forest management actions falls along a continuum from high to low importance depending on the individual and interacts with perceptions of risk associated with existing threats to forests, as demonstrated in other studies of private forest owners (Bissonnette et al. 2017, Vulturius et al. 2018).

A growing number of studies investigate forest owner intentions and actions on climate change adaptation (Blennow and Persson 2009, Blennow 2012, Blennow et al. 2012, Grotta et al. 2013, 
Table 1. Overview of property-level climate adaptation recommendations from the literature for dry mixed conifer forests in western North America. Int: Outcome of intentional adaptation. Inc: Outcome of incidental adaptation.

\begin{tabular}{|c|c|c|c|}
\hline \multicolumn{4}{|c|}{ Property-level forest management recommendations } \\
\hline \multicolumn{2}{|c|}{ Structure } & \multicolumn{2}{|c|}{ Composition } \\
\hline \multirow[t]{2}{*}{ Density management } & $\begin{array}{c}\text { Thinning (Int/Inc) } \\
\text { Thinning to wider-than-historic } \\
\text { spacing (Int/Inc) }\end{array}$ & Assisted migration & $\begin{array}{c}\text { Traditional or molecular breeding } \\
\text { to alter within-species genetic } \\
\text { composition (Int) }\end{array}$ \\
\hline & $\begin{array}{l}\text { Replanting following logging or } \\
\text { natural disturbances at lower } \\
\text { densities (Int) }\end{array}$ & & $\begin{array}{l}\text { Selecting provenances/species for } \\
\text { retention or replanting that are } \\
\text { "future-adapted" for a given site } \\
\text { type (Int) }\end{array}$ \\
\hline \multirow[t]{2}{*}{ Fuels reduction } & $\begin{array}{l}\text { Manual/mechanical fuels removal } \\
\text { (Int/Inc) }\end{array}$ & Diversification & $\begin{array}{l}\text { Planting or maintaining multiple } \\
\text { species as a "bet-hedging" strategy } \\
\text { (Int/Inc) }\end{array}$ \\
\hline & Prescribed fire (Int/Inc) & & \\
\hline
\end{tabular}

Lawrence and Marzano 2014, van Gameren and Zaccai 2015, Sousa-Silva et al. 2016, André et al. 2017, Bissonnette et al. 2017, Vulturius et al. 2018). In Sweden, approximately $20 \%$ of nonindustrial private forest owners reported adapting their forest management to climate change in some way (Blennow and Persson 2009, Blennow 2012) while $40 \%$ reported an intention to adapt (Vulturius et al. 2018). Nearly half of forest owners in Germany and Portugal reported implementing adaptation actions (Blennow et al. 2012). Additional case studies suggest low engagement with adaptation in Wales and moderate levels of engagement in Belgium (Lawrence and Marzano 2014, van Gameren and Zaccai 2015). Researchers classified half of Belgian interview respondents as climate change-motivated adaptors and one-third as incidental adaptors (van Gameren and Zaccai 2015). Across all studies, the most commonly reported adaptation actions were increasing tree species diversity and diversifying age structures, in addition to some intentional selection of future climate-adapted species (Blennow 2012, van Gameren and Zaccai 2015, Sousa-Silva et al. 2016, Bissonnette et al. 2017).

The importance of structural versus subjective barriers to climate change adaptation among private forest owners appears to depend on context. Studies from Sweden indicate cognitive factors, specifically strength of belief in anthropogenic climate change, overwhelmingly predict adaptation intention or action (Blennow and Persson 2009, Vulturius et al. 2018). There is also evidence that those with strong climate change beliefs who are not adapting perceive they have low adaptive capacity (Blennow and Persson 2009, van Gameren and Zaccai 2015). In contrast, in Belgium belief in climate change is a poor predictor of adaptation, likely because levels of belief among private forest owners are universally high. Instead, the structural barrier of poor access to technical information on adaptation is the most important factor constraining adaptation (van Gameren and Zaccai 2015). In Québec, eastern Canada, despite the majority reportedly perceiving anthropogenic climate change, three quarters of landowners perceive limited or nonexistent impacts on forests in the short and medium term and feel no need to adapt (Bissonnette et al. 2017). Finally, a series of forest owner focus groups across the U.S. Pacific Northwest and Alaska in 20092010 found that very few reported changing or adapting forest management practices in response to climate change (Grotta et al. 2013). To our knowledge there are no other studies of climate change adaptation among individual private forest owners in western North America.

\section{Adaptation in conifer forests of the western USA}

Our case study investigates climate change adaptation among nonindustrial private forest owners in Oregon's Blue Mountain ecoregion in the Inland Pacific Northwest, USA. Warminginduced declines in snowpack are expected to increase the frequency and intensity of drought stress, reduce tree growth and survival, increase disturbance by wildfire, insects and disease, and change forest composition and structure (Chmura et al. 2011, Spies et al. 2014, Halofsky and Peterson 2016). The annual percent area burned is projected to increase by $36 \%$ assuming fire suppression is maintained under a high emissions scenario (RCP 8.5; Sheehan et al. 2015, Dalton et al. 2017).

Table 1 shows common recommendations for adaptation in dry mixed conifer forests of western North America to respond to these changes (Chmura et al. 2010, Keenan 2015, Halofsky and Peterson 2016). We considered whether these recommended actions could result from intentional or incidental pathways to adaptation, and concluded that several recommended adaptations could result from both. There are additional recommendations for regional-level climate-adaptive forest management (e.g., Hessburg et al. 2015), but here we focus on feasible actions for individual landowners.

\section{Study goals}

A 2014 telephone survey of the general public in eastern Oregon found that although $84 \%$ of respondents say they believe climate change is happening, they are roughly split on whether current changes have human $(43 \%)$ or natural $(41 \%)$ causes (Boag et al. 2015). These causal beliefs are highly politicized, and generally align with liberal and conservative political affiliations, respectively (Hamilton et al. 2016, 2018, Dunlap et al. 2016). Doubt regarding the anthropogenic causes of climate change is widespread in other noncoastal areas of the western U.S. (Howe et al. 2015). At the same time, large wildfires have become more frequent in recent years, partly due to climate change, but also because of high fuels loads caused by 20 th century and ongoing 
fire suppression (Hamilton et al. 2016, Abatzoglou and Williams 2016). Therefore, forest owners in the western U.S. exist in a social and environmental context that may complicate climate change risk perceptions and motivations for adaptation. Focusing on wildfire risk mitigation through fuels reduction may simultaneously achieve climate adaptation benefits.

Using an actor-centered perspective recommended by Eisenack et al. (2014), we aim to advance understanding of opportunities for and barriers to adaptation among forest owners. We orient our investigation around the three general phases of adaptation (Moser and Ekstrom 2010). The understanding phase involves problem detection and information gathering; the planning phase involves developing and selecting adaptation options; and the management phase involves implementation, monitoring, and evaluation. This orientation is useful because it tracks forest management decisions from idea formation through evaluating options to prioritizing and taking actions, while recognizing that decision makers do not always progress sequentially from one stage to the next (Moser and Ekstrom 2010).

First, we identify the adaptive actions nonindustrial private forest owners in eastern Oregon have taken or intend to take. We also consider whether those actions are anticipatory or reactive to climate change and/or intentional or incidental. We argue this distinction is important when evaluating adaptation, because it distinguishes between incremental adaptation designed to help systems resist or be resilient to ongoing threats, versus transformational adaptations in the form of new practices designed to prepare systems for future threats that are outside the historic range of variability (Klein et al. 2014, Yousefpour et al. 2017). Second, we identify existing structural and subjective barriers to those adaptive actions, and compare our findings to those from other studies of private forest owners to understand which are most important for specific intentional or incidental adaptation actions. We hypothesized that individuals who do not believe anthropogenic climate change is occurring would not engage in intentional climate change adaptation, representing a subjective barrier. But, we hypothesized that they may demonstrate high levels of incidental adaptation due to high wildfire risk in the region. We also hypothesized that most of the structural barriers to adaptation would be nonclimate specific and similar to those identified in other regions with low economic and institutional capacity for active forest management. We supplement our qualitative analysis with excerpts from participant interviews to provide a richer picture of their perspectives for researchers, nonprofits, agencies and peers working to support climate-smart forest management.

\section{METHODS}

\section{Study area}

We conducted interviews with nonindustrial private forest owners in eastern Oregon, USA in the Blue Mountains ecoregion, which extends into parts of Idaho and Washington states. Oregon's largest ecoregion comprises rugged mountains and steep valleys and plateaus, with elevations ranging from 500 to over $3000 \mathrm{~m}$. Temperatures vary widely between seasons, with winter lows below $-15^{\circ} \mathrm{C}$ and summer highs above $35^{\circ} \mathrm{C}$ (NOAA 2017). Average annual precipitation was $40 \mathrm{~cm}$ over 1981-2010, with most precipitation falling in winter and spring as snow and rain and little precipitation in summer and fall, the region's fire season
(NOAA 2017). Dominant forest types in warm/dry sites and at low elevations are ponderosa pine (Pinus ponderosa) and warm mixed-conifer forests, while cool mixed-conifer and lodgepole pine forests (Pinus contorta) exist on cool/wet sites and at high elevations (Emmingham et al. 2005). Approximately $71 \%$ of eastern Oregon forests are federally owned, while $27 \%$ are privately owned and $2 \%$ are managed by nonfederal agencies (Campbell et al. 2003).

We performed all interviews in four counties (Crook, Wheeler, Grant, and Wallowa; Figure 1), selected for their diverse social and ecological contexts. Furthest west, Crook, Wheeler, and Grant counties lie in the rain shadow of the Cascade Mountains. These counties have cool mixed-conifer forest at high elevations, large swaths of dry mixed conifer and ponderosa pine forest at mid elevations, and western juniper (Juniperus occidentalis) woodlands and shrub steppe at lower elevations. Grant is the only county that still has a working lumber mill, while Crook and Wheeler counties are closest to large population centers like Bend. Wallowa County in Oregon's northeast corner is cooler and wetter with larger areas of cool mixed-conifer forest at lower elevations. Wallowa also has a larger proportion of seasonal property owners and a larger tourism industry. Across all four counties, most private forestland is dominated by ponderosa pine and Douglasfir (Pseudotsuga menziesii), in addition to grand fir (Abies grandis) and lodgepole pine in mixed conifer sites.

Fig. 1. Study area showing number of interviews (in parentheses) conducted in each county.

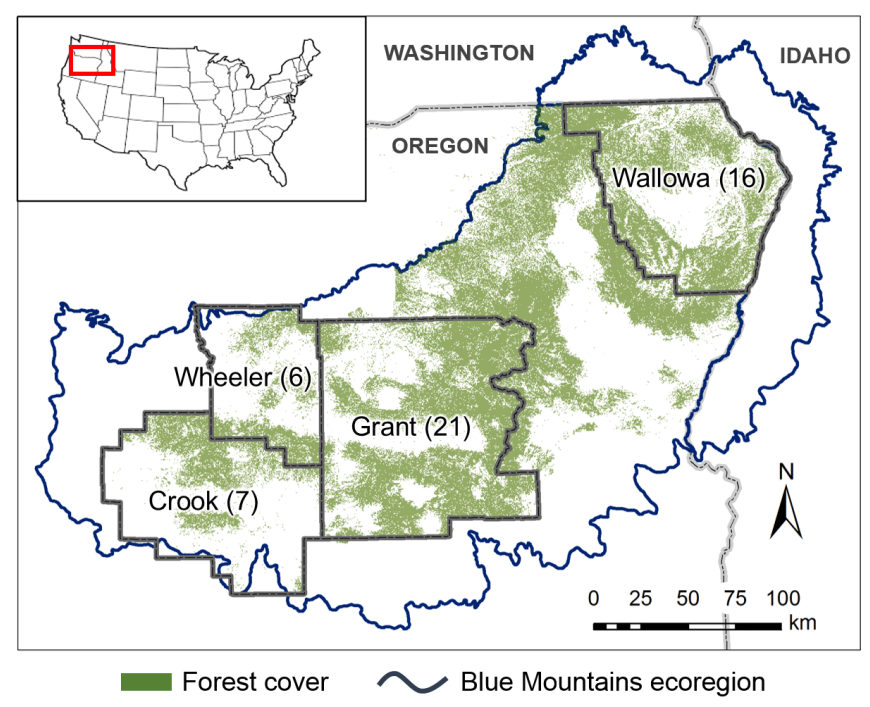

In eastern Oregon climate change impacts manifest as more frequent large wildfires, earlier springs, longer fire seasons, rising summer temperatures, and declining snowpack (Halofsky and Peterson 2016, Hamilton et al. 2016, Abatzoglou and Williams 2016). Fire suppression and overstory logging over the 20th century have also contributed to more frequent large wildfires, as in much of the U.S. West. Manufacturing, forestry, mining, and agriculture founded the area's economy, all of which continue to have a strong presence in the culture of local communities despite seeing significant declines in the last 30 years. Dramatic declines 
in logging in the 1990s due to policy changes on federal lands and other factors have shrunk the region's forest products industry infrastructure, including its workforce and log hauling capacity (Christoffersen 2005).

\section{Sampling frame and interview protocol}

We conducted an extensive literature review focusing on regional climate change impacts, wildfire history, as well as rural and environmental sociology to inform the development of a semistructured interview guide (Appendix 1), and conducted a pilot interview to refine our questions (Patton 2002). We identified landowners in each of the four counties owning greater than 4 ha (10 acres) forested land using publicly available tax lot data. We mailed them letters $(\mathrm{N}=417)$ inviting them to participate in the study (response rate $=7 \%$ ). The lead author then identified further participants through snowball sampling (Patton 2002), asking those who responded to our mailers to suggest other forest owners who may be interested in participating. Therefore, our participants represent a nonrandom self-selected group who are likely more interested and engaged in forest management than typical nonindustrial private forest owners in this region.

The lead author conducted all interviews to maintain topical consistency across all subjects and allow participants to respond in as much detail as they wished. Interviews covered six main topic areas: (1) management goals; (2) forest management planning; (3) management activities, both ongoing and planned; (4) perceptions of local wildfire risk, drought, changes in snow and precipitation, and forest condition; (5) beliefs and attitudes regarding climate change; and (6) engagement and resource needs. Participants were also asked to fill out a questionnaire on their demographic information. We intentionally asked about beliefs and attitudes regarding climate change near the end of the interviews to facilitate an open discussion of management goals, plans, actions, concerns, and perceptions of environmental change, and to maintain trust between the interviewer and participants.

A total of 50 landowners were interviewed between June and August 2015 (Wallowa county: 16; Grant county: 21; Wheeler county: 6; Crook county: 7). Interviews lasted from 45 minutes to two hours in length. Each respondent could decline to answer any question and end the interview at any point, though no one ended the interview prematurely. The interviewer volunteered to visit subjects on their properties, and in most cases the interviewer toured subjects' forest property with them during the interview. Interviews were audio-recorded with respondents' permission and also documented using extensive written notes. The audiotapes and interview notes were then transcribed for analysis.

Of the 50 respondents interviewed $72 \%$ lived on their property year-round, and most were well established in their communities. Many had lived in eastern Oregon for over 30 years (median = 37 ), and owned their properties for more than 20 years (median = 25). Property sizes of participants ranged from 6 to 5000 hectares $($ median $=57$ ha; Table 2$)$. Fifty-eight percent of respondents grazed cattle on some or all of their land (either their own cattle or leasing pasture to others), both in forested areas and pastures, and $30 \%$ of respondents also practiced other forms of agriculture, e.g., hay, crops such as canola and wheat, fruit orchards.
Table 2. Demographic characteristics of participants $(\mathrm{N}=50)$.

\begin{tabular}{lll}
\hline \hline Median age (years) & & 66 \\
Percent Male & & $80 \%$ \\
Median property area (ha) & & 57 \\
Property acquisition & Inherited & $26 \%$ \\
& Purchased & $74 \%$ \\
Plan to leave in five years & No & $96 \%$ \\
& Yes & $4 \%$ \\
Education & Less than High School & $2 \%$ \\
& High School & $14 \%$ \\
& Some College & $26 \%$ \\
& College & $44 \%$ \\
& Graduate School & $14 \%$ \\
Political orientation & Democrat & $12 \%$ \\
& Independent (lean Democrat) & $28 \%$ \\
& Independent & $18 \%$ \\
& Independent (lean Republican) & $12 \%$ \\
& Republican & $30 \%$ \\
\hline
\end{tabular}

\section{Data analysis}

We used a qualitative research approach because of its suitability for exploring the unique perceptions and activities of individual forest owners, particularly in the context of the emerging phenomenon of climate change adaptation (Bliss and Martin 1989, Creswell 2013, van Gameren and Zaccai 2015). We analyzed interview responses using inductive grounded theory (Glaser and Strauss 1967, Strauss and Corbin 1990), iteratively coding for emergent patterns and themes using NVivo 10.1 (QSR International). In contrast with a hypothetic-deductive approach, in grounded theory repeated themes and concepts are categorized, then these categories are compared and contrasted to form the basis for new theory (Strauss and Corbin 1994).

Based on the methods of a similar study by Nicholas and Durham (2012), answers to each question were grouped across all participants and initially coded using a pool of themes generated from five interviews. Interviews were coded for emergent themes and subthemes related to implemented or envisaged adaptation actions, overall forest management planning and actions, perceptions of local environmental change, beliefs regarding climate change, and resource limitations. Following the initial coding round, themes and subthemes were added, combined, or eliminated as needed in coding the rest of the interviews (Miles and Huberman 1994). After coding was complete, all transcripts were checked against the final code list (Appendix 1) to ensure all essential concepts were captured. We then compared individual cases by constructing qualitative data matrices in NVivo to explore patterns and connections between themes relating to cognitive and experiential factors, objective adaptive capacity, and forest management actions, including incidental and intentional adaptation actions.

\section{RESULTS}

\section{Forest management activities}

We asked respondents to describe their overall management goals for their land, and most landowners had multiple goals. The three most common goals reported by approximately half of the participants (either individually or in combination) were 
enhancing timber growth and yield, providing wildlife habitat, and developing and maintaining alternative amenity values. These alternative amenity values, which we coded as a single theme, included scenic value, solitude, aesthetics, and recreational opportunities. Approximately one quarter of participants had specific overall goals relating to habitat or forest restoration (including reducing wildfire risk), and procuring firewood. A small minority owned their land as a financial investment for themselves or their family.

We asked forest owners to recall their forest management actions over the last 10 years and most reported multiple actions on their land, though they varied by frequency and extent. Reported actions included precommercial thinning (removing nonsaleable brush, small trees); commercial thinning (selectively cutting trees as part of a timber sale); ground fuel removal (removing downed logs, branches, grass, and shrubs mechanically or manually); ladder fuel removal (limbing trees or removing small trees growing next to large trees), pile burning (burning woody fuels in piles); chipping (using a machine to chip woody fuels and spreading them or using as biomass for fuel); and using prescribed fire. We then classified owners by emergent categories representing how they manage forests on their property, and how useful their management actions are in the context of adapting dry conifer forests to climate change, whether intentional or not (Table 3). We considered those who commercially thinned and used prescribed fire as the most active managers in the context of climate change adaptation because numerous studies show combining these treatments reduces tree mortality following wildfires in North America's dry conifer forests (Raymond and Peterson 2005, Wimberly et al. 2009, Prichard et al. 2010).

Table 3. Emergent management categories.

\begin{tabular}{ll}
\hline \hline $\begin{array}{l}\text { Management category } \\
\text { (\# of owners) }\end{array}$ & Description \\
\hline Inactive (6) & $\begin{array}{l}\text { Have not yet carried out any forest } \\
\text { management activities on their property. } \\
\text { Moderately active (20) }\end{array}$ \\
$\begin{array}{l}\text { Performed some fuels management in the } \\
\text { form of precommercial thinning, prescribed } \\
\text { burns, manual ground fuel removal, } \\
\text { chipping, and/or pile burning. }\end{array}$ \\
$\begin{array}{l}\text { Commercially thinned all or a portion of } \\
\text { their property, and performed fuels } \\
\text { management in the form of precommercial } \\
\text { thinning, manual ground fuel removal, } \\
\text { chipping, and/or pile burning. } \\
\text { Commercially thinned all or a portion of } \\
\text { their property, performed fuels management } \\
\text { in the form of precommercial thinning, } \\
\text { manual ground fuel removal, chipping, and/ } \\
\text { or pile burning, and conducted prescribed } \\
\text { burns. }\end{array}$ \\
\hline
\end{tabular}

We did not observe connections between an individual's perceived risk of wildfire on their own property and their level of active forest management. Some of the most active managers viewed their wildfire risk as low because of their management, while others viewed risk as always high in their region. Some forest owners were very concerned about wildfires on adjacent public lands spreading onto their property, which they viewed as poorly managed, while others described how topographic, vegetation, and local weather conditions made risk variable over time.

Below, we present the intentional climate-adaptive forest management participants reported, followed by the barriers we identified. Illustrative quotes employ the respondents' ID codes, corresponding to their county of residence (C: Crook; WH: Wheeler; G: Grant; W: Wallowa).

\section{Climate-adaptive management actions}

Only two out of the 50 forest owners interviewed said they were intentionally managing their forest to adapt to climate change through anticipatory actions. The first of these two individuals expressed concern over the effects of climate change on area forests and were carrying out multiple forest management actions in response, putting them in the emergent category of "extremely active manager." They raised the issue unprompted following the first interview question about management goals and priorities:

\section{G14: Our goal is to maintain our property as a forested site in the face of climate change... I think that if areas in the southern Blue Mountains aren't managed it will be deforested-burned over and not reforested.}

Participant G14's primary concern was that climate change is contributing to increasingly large stand-replacing wildfires, and that future warming and more frequent drought would reduce and eventually prevent postfire seedling establishment and subsequent forest recovery. Therefore, they were taking comprehensive action to reduce the risk and impacts of wildfire on their property through thinning, limbing, prescribed burning, and annual manual fuel removal over their entire 40 acres (16 ha), with the exception of leaving some woody material as nurse sites for established seedlings, which we observed growing at low densities. They also purposely moved seed (cones) from their most vigorous ponderosa pine trees to sites they judged favorable for seedling establishment and growth. They also took steps to mitigate their contribution to climate change using on-site renewable energy generation.

The second landowner who reported intentionally adapting to climate change focused on species diversity as a "no-regrets" management strategy:

\section{G19: Global warming is a problem ... that's one of the reasons we're trying to keep diversity [in our forests].}

Both of these landowners indicated that they perceived sufficient risk of negative impacts on their forests from climate change that they were intentionally managing them in specific ways. Besides these landowners, seven other participants suggested, or "envisaged" (van Gameren and Zaccai 2015) potential adaptation actions that they might implement in the future, which generally aligned with the recommendations from forest scientists presented in Table 1. These included suggestions to change species composition and/or maintain species diversity, as well as more intensive thinning, however all of these individuals took a reactive approach to adaptation. The following quotes demonstrate this reactive approach:

W6: Yes, climate change will stress forests and trees will become disease prone and will die. Overall it may have effects on species, which ones can live in certain areas. I'm keeping an eye on it but I haven't planned explicitly 
Fig. 2. (A) Beliefs about climate change and its causes and (B) perceptions of local environmental change among nonindustrial private forest owners $(\mathrm{N}=50)$.

A.

Climate change beliefs

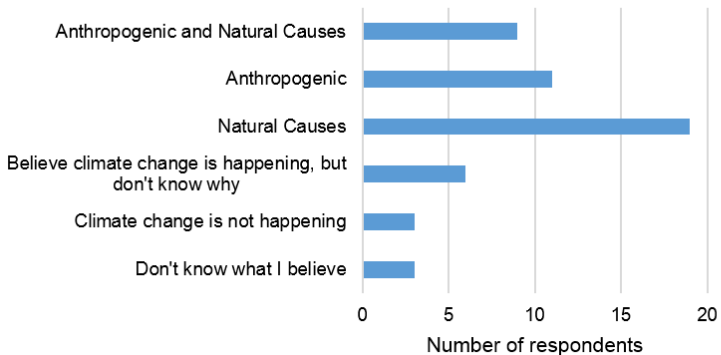

B. Perceived local environmental change

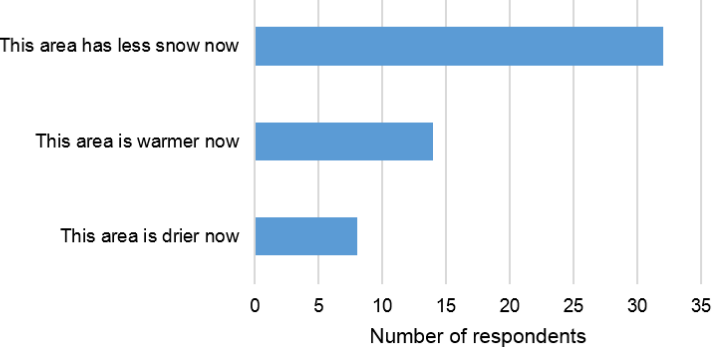

for it. I'm in watch and wait mode -[I have] talked to [Local Forester] about possibly needing to thin even more if drought happens.

G7: I'll continue to manage to reduce wildfire risk, I'll do what I've been doing. If I notice it getting drier and drier and drier, then yeah, I'll probably thin the inventory a bit.

C4: ... no one really knows what's going to happen, we haven't thought that far in advance -we would harvest if trees got too unhealthy.

These forest owners perceived potential future risks, but uncertainty about local climate change impacts and a lack of perceived immediate harms appeared to underlie their reactive approach.

In order to understand the potential role of planning for the future in adaptive thinking, we also asked individuals about forest management plans (FMPs) as well as how far into the future they planned their management actions. We then classified management plans by their quality in four emergent categories: comprehensive plans were those that were written down and included specific goals as well as a forest inventory (18 owners), while partial plans consisted of either an inventory or written goals (12 owners). Informal plans were those that individuals had "in their heads" (9 owners), and the rest had no management plan (10 owners). One landowner who comanaged their land with a relative was unsure of what type of plan they had.

Most reported taking forest management actions as the opportunity arose ( 24 owners), while others reported planning less than 10 years ahead (15 owners). Four planned $10-20$ years into the future, and four reported planning greater than 20 years into the future (three others did not answer this question). Most of the individuals who planned more than 10 years into the future had comprehensive management plans, and most of those who suggested or implemented adaptation actions had comprehensive plans. However, only two forest owners overlapped between these groups, because several of the forest owners planning more than 10 years ahead did so with the goal of optimizing timber rotations and enhancing logging profits, and were not necessarily concerned about climate change.

\section{Subjective barriers to adaptation}

We identified several subjective barriers to adaptation. First, beliefs about the cause of climate change affected individual risk perceptions and subsequent motivation to take action. The vast majority agreed that climate change is occurring, but many (19 owners) said climate change is due to "natural cycles" (Fig. 2A):

G3: I think there's some climate change, but I don't think it's human-caused. It's in a constant state of flux and there's not much we can do about it.

Some who believed the natural cycle explanation expressed hopes that the trajectory would change:

\section{C7: There's a warming trend, but we hope it's a natural} cycle and a short cycle.

Fewer thought it was due solely to anthropogenic activities (11 owners), and others attributed changes to a combination of anthropogenic activities and natural causes ( 9 owners; Fig. 2A):

G1: The pines are being stressed. Diplodia [a conifer disease ] was not an issue before -I think I'll lose 50\% of my seed trees in the next 5 years... The climate is changing, and some of it is a natural cycle and some of it is humans.

When asked about perceived local environmental change, the three most common landowner observations were that it is becoming hotter and drier, and most commonly that winter snowfall has declined considerably over the years (Fig. 2B).

The nine individuals who suggested or implemented intentional climate-adaptive actions did not report perceiving local environmental changes differently than those who did not discuss adaptation, primarily because most people, regardless of their beliefs about climate change, reported declines in snowpack. However, individuals who suggested or implemented climate change adaptation strategies more often believed that climate change is occurring because of anthropogenic activities (6 out of 9) than the broader pool of participants (11 out of 50). Others who believed climate change is due to anthropogenic activities speculated on potential impacts, but expressed uncertainties about local impacts, ultimately stopping short of discussing potential personal adaptations: 
WH3: I'm a personal believer in climate change. I'm not sure how it's playing out in our personal situation, but it would be interesting to see local climate data. Maybe less long cold spells? And that would result in more bugs in the forest.

W12: ...looking at scientific predictions we don't know what the local impacts will be, it's a huge question. We don't know what the effects are yet.

Overall, uncertainty was a common theme, including uncertainty around the cause of climate change and its future trajectory as well as its local implications.

\section{Structural barriers to adaptation}

To understand structural barriers to adaptation, we asked forest owners if they faced challenges implementing management actions or if there were specific resources they needed to accomplish their management goals. Common themes included a need for light logging equipment and more grant or cost-share funding to support activities (Table 4). Others were systemic barriers including weak forest product markets and therefore no financial incentive for active management, and a dearth of social capital, including insufficient communication between adjacent property owners and a lack of affordable local labor (Table 4).

We compared the resource needs of forest owners in each of the emergent active management categories, and found that inactive or moderately active managers generally reported multiple resource needs, while very active and extremely active managers generally reported only one or two resource needs, if any. Although this finding is intuitive, it reveals that addressing resource needs may facilitate active forest management, promoting both intentional and incidental adaptation. Some of the extremely active managers had learned how to successfully navigate grant and cost-share programs and used them to fund much of their management, while others owned sufficient timber or had the personal expertise and equipment, i.e., they were professional foresters themselves, to undertake forest thinning projects. Inactive and moderately active managers more commonly reported needing help with physical labor (either volunteer or paid) to help them carry out treatments.

We identified one final potential barrier to implementing climateadaptive forest management, which was the perceived trade-off between thinning and timber yields, as one participant explained:

W11: Less moisture means more stress on trees, more mortality, and higher burn risk. I want to leave things heavily stocked enough but ensure each tree is healthy. I' $m$ worried I may be leaving things too close -but I want to save merchantable timber.

This perceived dilemma underscores the intersection of structural barriers to adaptation, such as the costs associated with both carrying out management actions and potentially sacrificing merchantable timber, with subjective barriers, exemplified by uncertainty regarding drought-stress effects on trees and therefore what stocking levels are best moving forward.

\section{DISCUSSION}

Overall, our results demonstrate that intentional climate change adaptation generally has low salience among forest owners in eastern Oregon, and is much less common than in Europe,
Table 4. Common management resource constraints expressed by forest owners that pose barriers to intentional and incidental adaptation.

\begin{tabular}{|c|c|}
\hline Resource Need & Description \\
\hline Education & $\begin{array}{l}\text { Forest owners expressed a desire for more } \\
\text { workshops specific to local ecosystems. Some felt } \\
\text { that workshops were too basic or did not otherwise } \\
\text { align with their interests. Others were aware of } \\
\text { workshops but had not attended any yet, either } \\
\text { because they had not made it a priority, or because } \\
\text { of concerns over travel distance. }\end{array}$ \\
\hline Equipment & $\begin{array}{l}\text { Several owners expressed a desire for some kind of } \\
\text { equipment sharing, rental, or cooperative program } \\
\text { for light logging equipment, e.g., compact feller } \\
\text { buncher, and chippers, which may be too expensive } \\
\text { for individual owners to buy and maintain. }\end{array}$ \\
\hline $\begin{array}{l}\text { Grants/Cost- } \\
\text { share }\end{array}$ & $\begin{array}{l}\text { Some owners said they knew where to apply for } \\
\text { grants but had not done so yet, while others said } \\
\text { they did not know where to find information on } \\
\text { grants, and others said grants/cost-share programs } \\
\text { needed to provide more dollars. Some also } \\
\text { expressed reservations about grants because of the } \\
\text { stipulations of certain grants. }\end{array}$ \\
\hline Labor & $\begin{array}{l}\text { Many interviewees are of retirement age and said } \\
\text { that they needed help with labor. Several expressed } \\
\text { concerns that hiring labor is too expensive, that } \\
\text { there are not enough skilled forestry workers in their } \\
\text { area, or had concerns about liability. }\end{array}$ \\
\hline $\begin{array}{l}\text { Better forest } \\
\text { product markets }\end{array}$ & $\begin{array}{l}\text { Several landowners said they needed a profit } \\
\text { incentive to actively manage their forests, including } \\
\text { a market for small-diameter timber or a chip } \\
\text { market, and that log prices were too low to make } \\
\text { commercial thinning economically viable. } \\
\text { Specifically, with fewer mills in the region, several } \\
\text { respondents said log hauling costs were prohibitive } \\
\text { and undercut any income from timber sales. }\end{array}$ \\
\hline $\begin{array}{l}\text { Institutional } \\
\text { capacity }\end{array}$ & $\begin{array}{l}\text { A few landowners expressed a desire to work across } \\
\text { parcel boundaries with neighbors on forest } \\
\text { management, whether public or private neighbors. }\end{array}$ \\
\hline Time & $\begin{array}{l}\text { Many said they did not have time to do what needed } \\
\text { to be done, or that they would get around to taking } \\
\text { action eventually. }\end{array}$ \\
\hline
\end{tabular}

aligning with findings from focus groups performed in the western U.S. five years prior to our interviews (Grotta et al. 2013). However, a large majority of forest owners are implementing incidentally adaptive actions including thinning and general fuels management in service of other goals, including timber growth and yield, wildlife habitat, and wildfire risk mitigation. Additionally, by comparing one-fifth of forest owners who are either considering or implementing adaptation actions with those who are not, we identified multiple important subjective and structural barriers that constrain adaptation in different ways. Subjective barriers primarily barred intentional climate change adaptation, while structural barriers constrained both intentional and incidental adaptation. Our findings contribute to arguments that the importance of subjective versus structural barriers depends on context, and that they interact to determine adaptation outcomes (Eisenack et al. 2014).

Most forest owners in this case study agreed that climate change is occurring. However, beliefs about the causes of climate change 
Fig. 3. The adaptation process of nonindustrial forest owners in eastern Oregon, with arrows indicating connections between process components and outcomes. We identified important factors influencing individual adaptive capacity in the understanding, planning, and management phases of adaptation. Subjective and structural barriers to adaptation may arise at each stage, but beliefs about climate change and their effects on risk perceptions may primarily determine whether forest owners engage in intentional climate change adaptation. Forest management planning and individual adaptive capacity affect both intentional and incidental adaptation outcomes. $\dagger$ Adaptation actions reportedly implemented or \$suggested for future implementation by forest owners interviewed in this study; other listed adaptation outcomes are recommended by forest scientists but were not reported (see Table 1).

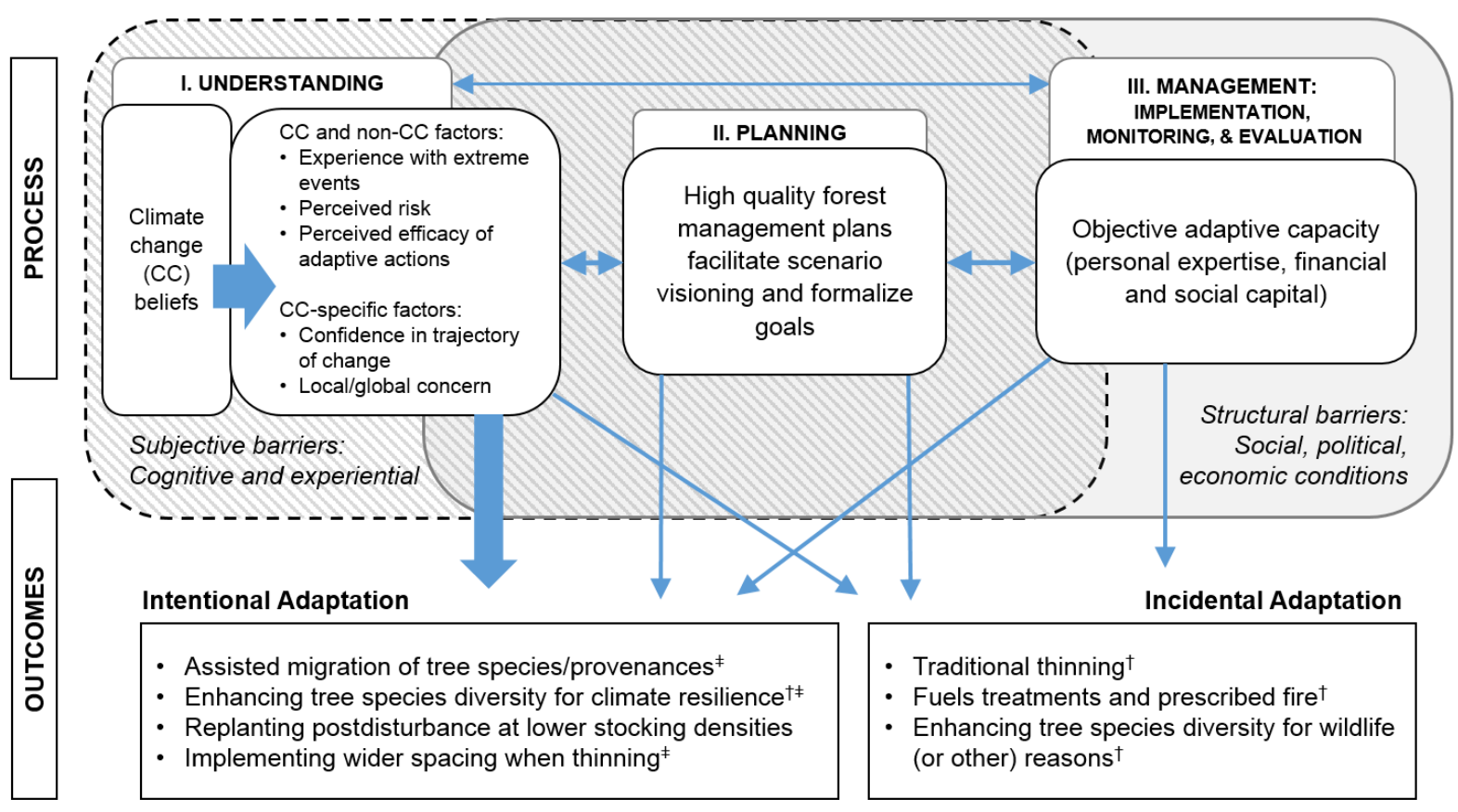

appeared to influence the ways in which acknowledgment of the phenomenon affected risk perceptions and motivations to adapt. Those who believed that climate change is occurring because of natural cycles were generally not confident about the future trajectory of climate change and its potential impacts, which likely reduced their level of concern and undercut motivations to take intentional adaptive actions. These individuals would likely be members of the "Doubtful" group of global warming's "Six Americas," a segmentation of the U.S. population by Leiserowitz et al. (2009). Aligning with this typology, many of these respondents were male, white, older, and Republican.

In contrast, the seven other landowners who suggested adaptation actions predominantly identified as Democrats, or left-leaning Independents, despite also being older and predominantly men. Along with the two landowners who intentionally implemented climate-adaptive management, they believed the scientific consensus that anthropogenic emissions cause climate change. Landowner G14, who described their intentionally climateadaptive forest management, had installed solar power and hot water heating to reduce their greenhouse gas emissions. They would likely fall into the "Alarmed" group of the Six Americas, while others who suggested potential adaptation actions align with the "Concerned" group (Leiserowitz et al. 2009). They possessed greater certainty that warming would continue in their local area, contributing to local environmental changes such as increasingly frequent wildfires, pests and disease, and drought stress in trees. In Figure 3, we illustrate the factors we observed impacting each stage of the adaptation process among private forest owners, including how climate change beliefs and concern operating in the understanding phase drive adaptation outcomes.

These findings align with those of a survey of Swedish private forest owners (Blennow and Persson 2009). That study found a strong, statistically significant association between strength of belief in climate change and taking steps toward adaptation. There has been a slow upward trend in U.S. public acceptance of anthropogenic climate change, rising above $60 \%$ by late 2017 (Hamilton 2017) though it was closer to $50 \%$ when these interviews were conducted in 2015 (Hamilton et al. 2015). The fraction of people who reject anthropogenic climate change remains sizable in the nation, and proportionately larger in eastern Oregon. This barrier is difficult to overcome because it is strongly tied to political and cultural identities, and may limit intentional climate change adaptation (Hamilton et al. 2015).

We observed a great deal of uncertainty about local climate change impacts and the efficacy of adaptation actions among individual landowners. This uncertainty not only precluded some landowners from considering adaptation actions, but also contributed to a reactive "wait-and-see" approach to adaptation. Although a reactive approach may be effective for addressing 
some impacts, such as drought stress impacts on individual trees, it may be maladaptive for reducing risks posed by increasingly frequent large wildfires and insect outbreaks, which may only be mitigated by more widespread reductions in tree densities or creating more heterogeneous tree coverage (Hessburg et al. 2015). This finding aligns with other studies finding forest owners view lack of access to easily interpreted information on local climate projections and adaptation options as a structural barrier to adaptation, which in turn impacts their subjective perception of personal adaptive capacity (Blennow and Persson 2009, Grotta et al. 2013, Lawrence and Marzano 2014, Sousa-Silva et al. 2016).

Forest owners who did not engage in widespread fuel reductions or other adaptive actions said they face multiple resource-based barriers to active forest management, impacting their adaptive capacity. These included insufficient time and financial resources and lack of access to equipment and labor. Removing these structural barriers may result in more climate-adaptive forest management, whether intentional or incidental (Fig. 3).

Forest owners with timber production goals were some of the most active managers we observed, with many performing thinning and fuel removal both to reduce wildfire risk and increase growth and yield. Although these incidental adaptations are beneficial, they may not be sufficient given projected climate impacts. Owners with timber production goals may have a conflict of interest between maximizing trees per acre and thinning to stocking levels that are more sustainable under hotter, drier conditions. A similar study in Belgium identified the same potential conflict (van Gameren and Zaccai 2015). Additionally, production-focused owners may prioritize fast-growing species and monocultures over future climate-adapted species or species diversification. Interview responses contained almost no discussion of planting trees using stock from hotter, drier regions, or intentionally favoring future climate-adapted species on specific sites. This perhaps should not be surprising because assisted migration is controversial and still gradually gaining traction in industrial forestry contexts, with only a few assisted migration policies arising in countries like Canada (Klenk 2015). However, our findings contrast with studies from Europe where adaptation-focused experimentation with species compositions is reportedly common (van Gameren and Zaccai 2015, Sousa-Silva et al. 2016). This difference may partly reflect the low species diversity of western North American conifer forests.

\section{Communication and policy recommendations}

We found uncertainty surrounding projected local climate change as a key factor underlying forest owners' justification for reactive approaches to adaptation. However, downscaled projections for climate change impacts exist for the Blue Mountains (Halofsky and Peterson 2016) as well as many other forested regions globally, suggesting this is a knowledge transfer problem (Sousa-Silva et al. 2016). Scientists and practitioners must clearly explain uncertainties associated with projected local impacts, and articulate adaptation actions that are likely to be effective, as well as those that represent "no regrets" strategies. Numerous studies indicate that this type of information is best delivered by trusted community members through experiential learning activities, such as forestry site tours and deliberative workshops (Hobson and Niemeyer 2011, Raymond and Robinson 2013, Klein et al. 2014). Organizations and agencies could cultivate local champions who can help make conversations about climate change and adaptation more socially acceptable. Climate scientists could also present at forest management training days, or contribute clearly written, simple articles outlining likely local scenarios to local newspapers and resource management newsletters. Strong governance signals in the form of supportive policies or programs are also essential for fostering public responses to climate change (Hobson and Niemeyer 2011).

At the same time, our work suggests that in regions where climate change discussions are politically charged and may lead to disengagement, it may also be beneficial to focus communication strategies on drivers of incidental adaptation such as wildfire risk. Incidental adaptation actions, although potentially insufficient on their own to ensure forest resilience long-term, will yield public benefits as the climate warms (Hartter et al. 2017).

We found that forest owners with comprehensive forest management plans often have longer planning horizons and more frequently suggested or implemented adaptation actions. The causality of this relationship may operate in both directions (individual concern about climate change and interest in adaptation may encourage these landowners to develop management plans; Fig. 3). However, the process of developing a management plan, especially if done with input from an outside expert, may encourage "visioning" of future conditions and consideration of the long-term implications of management decisions. Other studies indicate landowners with written forest management plans are more likely to engage in silvicultural activities and express interest in ecosystem management (Creighton et al. 2002, Joshi and Arano 2009). Therefore, forest management plans, land stewardship plans, or other private land management planning processes may be an effective intervention point for increasing private landowner engagement with adaptation.

Management plans with long planning horizons may increase the salience of projected climate change impacts. Most climate change projections are 30,50 , or 100 years in the future, timelines that may not be relevant to many private forest owners as shown elsewhere (Grotta et al. 2013, Bissonnette et al. 2017). In this study few forest owners planned greater than 10 years ahead. Oregon Forest Management Plan Guidelines (2013) currently recommend private forest owners write management plans with a 10 -year planning horizon. Extending this recommended horizon may encourage landowners to think about longer-term processes, including climate change impacts and adaptation. The USDA Forest Service's Climate Change Response Framework recognizes this, and has developed a detailed Adaptation Workbook for forest owners and managers in the U.S. Northeast and Midwest (Swanston and Janowiak 2012, Ontl et al. 2018), which provides adaptation recommendations and encourages both short $(<10$ years) and long-term management plans ( $>30$ years). Such a workbook would likely be beneficial for nonindustrial private forest owners in the western U.S.

Overall, our work suggests several specific recommendations for organizations and agencies supporting climate-adaptive forest management among nonindustrial private forest owners:

- Ecoregionally relevant education on climate change adaptation actions, including clear recommendations for tree density management and species composition. 
- Incentives to complete management plans with multidecadal time horizons.

- Cooperative or rental programs for light logging machinery and other equipment to lower management costs and facilitate active management.

- Accessible grant and cost-share programs to improve affordability of climate-adaptive forest management where markets for wood products are depressed.

- Multiparcel projects through collaborative structures or cooperative agreements that allow landowners to pool timber, financial resources, equipment and labor, including public-private partnerships to increase adaptation efficiencies.

Some of these recommendations are likely relevant to climate change adaptation on private lands in a variety of socialecological systems. These include managing to reduce flood and erosion risks, enhancing water availability in arid regions, and maintaining wildlife habitat.

\section{Limitations}

We recognize that by conducting these interviews over the span of a single summer in 2015, our findings may not reflect evolving views among nonindustrial private forest owners. Near the end of that summer eastern Oregon experienced several large, highseverity wildfires, in which over 30 families lost their homes. These events could have changed levels of concern about climate change, though in affiliated telephone interviews we conducted we saw no change between the fall of 2014 and 2015 in beliefs about the cause of climate change (Hamilton, unpublished data).

The forest owners we interviewed are also likely far more active than the average forest owner in eastern Oregon. Most volunteered to participate or were referred by another landowner, indicating they are at least somewhat engaged in their community and interested in forest management. Approximately half of the participants had commercially thinned a portion of their property. A large mail survey of forest owners in this region and the nearby eastern Cascade Mountains found 36\% reported thinning with mechanized equipment, and $29 \%$ reported harvesting timber for profit between 2003 and 2008 (Fischer and Charnley 2012), indicating that our participants are likely more active than typical forest owners. We also asked participants about their participation in forestry workshops, and roughly half reported attending workshops held by Oregon State University Extension (Boag, unpublished data), aligning with findings from another mail survey previously conducted in this region (Hartter et al. 2015). Random sample telephone or mail surveys and inferential statistics would be necessary to evaluate the connections we identified in this qualitative study between climate change beliefs, forest management planning, resource needs, and adaptation outcomes.

\section{CONCLUSION}

This study contributes to a growing body of research on opportunities for and barriers to climate change adaptation among private forest owners, and individual decision makers more broadly. The forestry community should exploit synergies between managing forests for improved growth and yield, mitigating wildfire and other existing risks, and climate-adaptive forest management. In western North America, addressing existing resource needs for fuel reductions and density management will contribute to this synergistic approach. However, scientists, university extension services, and agencies supporting private landowners should also continue to advance conversations about intentional climate change adaptation, while being sensitive to political polarization on the issue. Incidental and/or reactive adaptation may be an effective strategy for adapting to some climate change impacts including sporadic drought (e.g., thin when trees start to look stressed), however it may be ineffective in terms of long-term social, political, and economic costs. Believing anthropogenic climate change is occurring is a precursor to accepting that local warming and its associated impacts on forests will continue through the $21 \mathrm{st}$ century, unless emissions are dramatically reduced. Confidence in the trajectory of change is necessary to begin conversations about thinning forests below historical stocking levels or favoring certain tree species.

This logic extends to decisions that may be made by groups of forest owners. Some very new groups of nonindustrial private forest owners such as the Ritter Land Management Team (https:// www.ritterlmt.com/about.html) in eastern Oregon are emerging to pool resources and carry out multiparcel forest management projects across private lands. They are also interfacing with state and federal agencies to engage in an "all lands approach" to forest management (Charnley et al. 2017). In forestry and other sectors, understanding barriers to adaptation among individual landowners will improve existing and potential adaptation strategies, enhancing the management of social-ecological systems as the climate changes.

Responses to this article can be read online at: http://www.ecologyandsociety.org/issues/responses. php/10355

\section{Acknowledgments:}

This work is supported by the United States Department of Agriculture (USDA) National Institute of Food and Agriculture (NIFA) (2014-68002-21782). Any opinions, findings, conclusions or recommendations expressed in this material are those of the authors and do not necessarily represent the views of NIFA or USDA. We appreciate continued collaboration with the USDA Forest Service and the Oregon Department of Forestry. This study complies with U.S. law and is approved by the Institutional Review Board for the Protection of Human Subjects in Research at the University of Colorado Boulder and the University of New Hampshire.

\section{LITERATURE CITED}

Abatzoglou, J. T., and A. P. Williams. 2016. Impact of anthropogenic climate change on wildfire across western US forests. Proceedings of the National Academy of Sciences 113 (42):11770-11775. http://dx.doi.org/10.1073/pnas.1607171113

Adger, W. N., S. Agrawala, M. M. Q. Mirza, C. Conde, K. O’Brien, J. Pulhin, R. Pulwarty, B. Smit, and K. Takahashi. 2007. 
Assessment of adaptation practices, options, constraints and capacity. Pages 717-743 in M. L. Parry, O. F. Canziani, J. P. Palutikof, P. J. van der Linden and C. E. Hanson, editors. Climate change 2007: impacts, adaptation and vulnerability. Contribution of Working Group II to the Fourth Assessment Report of the Intergovernmental Panel on Climate Change. Cambridge University Press, Cambridge, UK.

Adger, W. N., S. Dessai, M. Goulden, M. Hulme, I. Lorenzoni, D. R. Nelson, L. O. Naess, J. Wolf, and A. Wreford. 2009. Are there social limits to adaptation to climate change? Climatic Change 93(93). http://dx.doi.org/10.1007/s10584-008-9520-Z

Agard, J., E. L. F. Schipper, J. Birkmann, M. Campos, C. Dubeux, Y. Nojiri, L. Olsson, B. Osman-Elasha, M. Pelling, M. J. Prather, M. G. Rivera-Ferre, O. C. Ruppel, A. Sallenger, K. R. Smith, A. L. St Clair, K. J. Mach, M. D. Mastrandrea, and T. E. Bilir, editors. 2014. Annex II: glossary. Pages 1757-1776 in V. R. Barros, C. B. Field, D. J. Dokken, M. D. Mastrandrea, K. J. Mach, T. E. Bilir, M. Chatterjee, K. L. Ebi, Y. O. Estrada, R. C. Genova, B. Girma, E. S. Kissel, A. N. Levy, S. MacCracken, P. R. Mastrandrea, and L. L. White, editors. Climate change 2014: impacts, adaptation, and vulnerability. Part B: regional aspects. Working Group II Contribution to the IPCC Fifth Assessment Report. Cambridge University Press, Cambridge, UK.

Ager, A. A., N. M. Vaillant, M. A. Finney, and H. K. Preisler. 2012. Analyzing wildfire exposure and source-sink relationships on a fire prone forest landscape. Forest Ecology and Management 267:271-283. http://dx.doi.org/10.1016/j.foreco.2011.11.021

Agrawal, S., and M. C. Monroe. 2006. Using and improving social capital to increase community preparedness for wildfire. Pages 163-167 in S. M. McCaffrey, technical editor. The public and wildland fire management: social science findings for managers. General Technical Report NRS-1. U.S. Forest Service, Northern Research Station, Newtown Square, Pennsylvania, USA.

Akerlof, K., E. W. Maibach, D. Fitzgerald, A. Y. Cedeno, and A. Neuman. 2013. Do people "personally experience" global warming, and if so how, and does it matter? Global Environmental Change 23(1):81-91. http://dx.doi.org/10.1016/j.gloenvcha.2012.07.006

Amundsen, H., F. Berglund, and H. Westskog. 2010. Overcoming barriers to climate change adaptation: a question of multilevel governance? Environment and Planning C: Politics and Space 28 (2):276-289. http://dx.doi.org/10.1068/c0941

André, K., J. Baird, Å. Gerger Swartling, G. Vulturius, and R. Plummer. 2017. Analysis of Swedish forest owners' information and knowledge-sharing networks for decision-making: insights for climate change communication and adaptation. Environmental Management 59(6):885-897. http://dx.doi.org/10.1007/s00267-017-0844-1

Beck, U. 1992. Risk society: towards a new modernity. Sage, London, UK.

Biesbroek, G. R., J. E. M. Klostermann, C. J. A. M. Termeer, and P. Kabat. 2013. On the nature of barriers to climate change adaptation. Regional Environmental Change 13(5):1119-1129. http://dx.doi.org/10.1007/s10113-013-0421-y

Bissonnette, J.-F., J. Dupras, F. Doyon, C. Chion, and J. Tardif. 2017. Perceptions of small private forest owner's vulnerability and adaptive capacity to environmental disturbances and climate change: views from a heterogeneous population in southern Quebec, Canada. Small-Scale Forestry 16(3):367-393. http://dx. doi.org/10.1007/s11842-016-9361-y

Blennow, K. 2012. Adaptation of forest management to climate change among private individual forest owners in Sweden. Forest Policy and Economics 24:41-47. http://dx.doi.org/10.1016/j. forpol.2011.04.005

Blennow, K., and J. Persson. 2009. Climate change: motivation for taking measure to adapt. Global Environmental Change 19 (1):100-104. http://dx.doi.org/10.1016/j.gloenvcha.2008.10.003

Blennow, K., J. Persson, M. Tomé, and M. Hanewinkel. 2012. Climate change: believing and seeing implies adapting. PLoS ONE 7(11):e50182. http://dx.doi.org/10.1371/journal.pone.0050182

Bliss, J. C., and A. J. Martin. 1989. Identifying NIPF management motivations with qualitative methods. Forest Science 35 (2):601-622.

Boag, A. E., J. Hartter, L. C. Hamilton, F. R. Stevens, M. J. Ducey, M. W. Palace, N. D. Christoffersen, and P. T. Oester. 2015. Forest views: shifting attitudes toward the environment in northeast Oregon. Paper 238. Carsey School of Public Policy, University of New Hampshire, Durham, New Hampshire, USA.

Butler, B. J., J. H. Hewes, B. J. Dickinson, K. Andrejczyk, S. M. Butler, and M. Markowski-Lindsay. 2016. Family forest ownerships of the United States, 2013: findings from the USDA Forest Service's national woodland owner survey. Journal of Forestry 114(6):638-647. http://dx.doi.org/10.5849/jof.15-099

Campbell, S., D. Azuma, and D. Weyermann. 2003. Forests of eastern Oregon: an overview. General Technical Report PNWGTR-578. U.S. Forest Service, Pacific Northwest Research Station, Portland, Oregon, USA. http://dx.doi.org/10.2737/ PNW-GTR-578

Carter, T. R. 1996. Assessing climate change adaptations: the IPCC guidelines. Pages 27-43 in J. B. Smith, N. Bhatti, G. V. Menzhulin, R. Benioff, M. Campos, B. Jallow, F. Rijsberman, M. I. Budyko, and R. K. Dixon, editors. Adapting to climate change: an international perspective. Springer-Verlag, New York, New York, USA. http://dx.doi.org/10.1007/978-1-4613-8471-7 4

Charnley, S., E. C. Kelly, and K. L. Wendel. 2017. All lands approaches to fire management in the Pacific West: a typology. Journal of Forestry 115(1):16-25. http://dx.doi.org/10.5849/ jof.15-092

Chmura, D. J., P. D. Anderson, G. T. Howe, C. A. Harrington, J. E. Halofsky, D. L. Peterson, D. C. Shaw, and J. B. St.Clair. 2011. Forest responses to climate change in the northwestern United States: ecophysiological foundations for adaptive management. Forest Ecology and Management 261(7):1121-1142. http://dx.doi. org/10.1016/j.foreco.2010.12.040

Chmura, D. J., G. T. Howe, P. D. Anderson, and J. B. St Clair. 2010. Adaptation of trees, forests and forestry to climate change. SYLWAN 154(9):587-602.

Christoffersen, N. D. 2005. Wallowa resources: gaining access and adding value to natural resources on public lands. Pages 147-180 in B. Child and W. M. Lyman, editors. Natural resources as community assets: lessons from two continents. The Sand County Foundation and The Aspen Institute, Madison, Wisconsin, USA. 
Clark, J. S., L. Iverson, C. W. Woodall, C. D. Allen, D. M. Bell, D. C. Bragg, A. W. D'Amato, F. W. Davis, M. H. Hersh, I. Ibanez, S. T. Jackson, S. Matthews, N. Pederson, M. Peters, M. W. Schwartz, K. M. Waring, and N. E. Zimmermann. 2016. The impacts of increasing drought on forest dynamics, structure, and biodiversity in the United States. Global Change Biology 22 (7):2329-2352. http://dx.doi.org/10.1111/gcb.13160

Creighton, J. H., D. M. Baumgartner, and K. A. Blatner. 2002. Ecosystem management and nonindustrial private forest landowners in Washington State, USA. Small-scale Forest Economics, Management and Policy 1(1):55-69.

Creswell, J. W. 2013. Five qualitative approaches to inquiry. Pages 69-110 in J. W. Creswell and C. N. Poth, editors. Qualitative inquiry \& research design: choosing among five approaches. Sage, Thousand Oaks, California, USA.

Dalton, M. M., K. D. Dello, L. Hawkins, P. W. Mote, and D. E. Rupp. 2017. The Third Oregon Climate Assessment Report. Oregon Climate Change Research Institute, Corvallis, Oregon.

Dunlap, R. E., A. M. McCright, and J. H. Yarosh. 2016. The political divide on climate change: partisan polarization widens in the U.S. Environment: Science and Policy for Sustainable Development 58(5):4-23. http://dx.doi.org/10.1080/00139157.2016.1208995

Eisenack, K., S. C. Moser, E. Hoffmann, R. J. T. Klein, C. Oberlack, A. Pechan, M. Rotter, and C. J. A. M. Termeer. 2014. Explaining and overcoming barriers to climate change adaptation. Nature Climate Change 4(10):867-872. http://dx.doi. org/10.1038/nclimate2350

Eisenack, K., and R. Stecker. 2012. A framework for analyzing climate change adaptations as actions. Mitigation and Adaptation Strategies for Global Change 17(3):243-260. http://dx.doi. org/10.1007/s11027-011-9323-9

Emmingham, W. H., P. T. Oester, S. A. Fitzgerald, G. M. Filip, and W. D. Edge. 2005. Ecology and management of eastern Oregon forests: a comprehensive manual for forest managers. Oregon State University, Corvallis, Oregon, USA.

Enright, N. J., J. B. Fontaine, D. M. Bowman, R. A. Bradstock, and R. J. Williams. 2015. Interval squeeze: altered fire regimes and demographic responses interact to threaten woody species persistence as climate changes. Frontiers in Ecology and the Environment 13(5):265-272. http://dx.doi.org/10.1890/140231

Fischer, A. P., and S. Charnley. 2012. Risk and cooperation: managing hazardous fuel in mixed ownership landscapes. Environmental Management 49(6):1192-1207. http://dx.doi. org/10.1007/s00267-012-9848-Z

Fischer, A. P., J. D. Kline, A. A. Ager, S. Charnley, and K. A. Olsen. 2014. Objective and perceived wildfire risk and its influence on private forest landowners' fuel reduction activities in Oregon's (USA) ponderosa pine ecoregion. International Journal of Wildland Fire 23(1):143-153. http://dx.doi.org/10.1071/WF12164

Glaser, B. G., and A. L. Strauss. 1967. The discovery of grounded theory: strategies for qualitative research. Transaction, New Brunswick, New Jersey, USA.

Grant, G. E., C. L. Tague, and C. D. Allen. 2013. Watering the forest for the trees: an emerging priority for managing water in forest landscapes. Frontiers in Ecology and the Environment 11 (6):314-321. http://dx.doi.org/10.1890/120209

Grothmann, T., and A. Patt. 2005. Adaptive capacity and human cognition: the process of individual adaptation to climate change. Global Environmental Change 15(3):199-213. http://dx.doi. org/10.1016/j.gloenvcha.2005.01.002

Grotta, A. T., J. H. Creighton, C. Schnepf, and S. Kantor. 2013. Family forest owners and climate change: understanding, attitudes, and educational needs. Journal of Forestry 111(2):87-93. http://dx.doi.org/10.5849/jof.12-052

Halofsky, J. E., and D. L. Peterson. 2016. Climate change vulnerability and adaptation in the Blue Mountains Region. U.S. Forest Service, Pacific Northwest Research Station Portland, Oregon, USA.

Hamilton, L. 2017. Data snapshot: public acceptance of humancaused climate change is gradually rising. Carsey School of Public Policy, University of New Hampshire, Durham, New Hampshire, USA.

Hamilton, L. C., E. Bell, J. Hartter, and J. D. Salerno. 2018. A change in the wind? US public views on renewable energy and climate compared. Energy, Sustainability and Society 8(1). http:// dx.doi.org/10.1186/s13705-018-0152-5

Hamilton, L. C., J. Hartter, B. D. Keim, A. E. Boag, M. W. Palace, F. R. Stevens, and M. J. Ducey. 2016. Wildfire, climate, and perceptions in northeast Oregon. Regional Environmental Change 16(6):1819-1832. http://dx.doi.org/10.1007/s10113-015-0914-y

Hamilton, L. C., J. Hartter, M. Lemcke-Stampone, D. W. Moore, and T. G. Safford. 2015. Tracking public beliefs about anthropogenic climate change. PLOS ONE 10(9):e0138208. http://dx.doi.org/10.1371/journal.pone.0138208

Hartter, J., L. C. Hamilton, A. E. Boag, F. R. Stevens, M. J. Ducey, N. D. Christoffersen, P. T. Oester, and M. W. Palace. 2017. Does it matter if people think climate change is human caused? Climate Services 10:53-62. http://dx.doi.org/10.1016/j.cliser.2017.06.014

Hartter, J., F. R. Stevens, L. C. Hamilton, R. G. Congalton, M. J. Ducey, and P. T. Oester. 2015. Modelling associations between public understanding, engagement and forest conditions in the inland Northwest, USA. PLoS ONE 10(2):e0117975. http://dx. doi.org/10.1371/journal.pone.0117975

Hessburg, P. F., D. J. Churchill, A. J. Larson, R. D. Haugo, C. Miller, T. A. Spies, M. P. North, N. A. Povak, R. T. Belote, P. H. Singleton, W. L. Gaines, R. E. Keane, G. H. Aplet, S. L. Stephens, P. Morgan, P. A. Bisson, B. E. Rieman, R. B. Salter, and G. H. Reeves. 2015. Restoring fire-prone Inland Pacific landscapes: seven core principles. Landscape Ecology 30(10):1805-1835. http://dx.doi.org/10.1007/s10980-015-0218-0

Hobson, K., and S. Niemeyer. 2011. Public responses to climate change: the role of deliberation in building capacity for adaptive action. Global Environmental Change 21(3):957-971. http://dx. doi.org/10.1016/j.gloenvcha.2011.05.001

Howe, P. D., M. Mildenberger, J. R. Marlon, and A. Leiserowitz. 2015. Geographic variation in opinions on climate change at state and local scales in the USA. Nature Climate Change 5(6):596-603. http://dx.doi.org/10.1038/nclimate2583 
Joshi, S., and K. G. Arano. 2009. Determinants of private forest management decisions: a study on West Virginia NIPF landowners. Forest Policy and Economics 11(2):118-125. http:// dx.doi.org/10.1016/j.forpol.2008.10.005

Kahan, D. M., M. Wittlin, E. Peters, P. Slovic, L. Larrimore Ouellette, D. Braman, and G. N. Mandel. 2011. The tragedy of the risk-perception commons: culture conflict, rationality conflict, and climate change. Temple University Legal Studies Research Paper No. 2011-26; Cultural Cognition Project Working Paper No. 89; Yale Law \& Economics Research Paper No. 435; Yale Law School, Public Law Working Paper No. 230. http://dx.doi. org/10.2139/ssrn.1871503

Keenan, R. J. 2015. Climate change impacts and adaptation in forest management: a review. Annals of Forest Science 72 (2):145-167. http://dx.doi.org/10.1007/s13595-014-0446-5

Keskitalo, E. C. H., N. Klenk, R. Bullock, A. L. Smith, and D. R. Bazely. 2011. Preparing for and responding to disturbance: examples from the forest sector in Sweden and Canada. Forests 2(2):505-524. http://dx.doi.org/10.3390/f2020505

Klein, R. J. T., G. F. Midgley, B. L. Preston, M. Alam, F. G. H. Berkhout, K. Dow, and M. R. Shaw. 2014. Adaptation opportunities, constraints, and limits. Pages 899-943 in C. B. Field, V. R. Barros, D. J. Dokken, K. J. Mach, M. D. Mastrandrea, T. E. Bilir, M. Chatterjee, K. L. Ebi, Y. O. Estrada, R. C. Genova, B. Girma, E. S. Kissel, A. N. Levy, S. MacCracken, P. R. Mastrandrea, and L. L. White, editors. Climate change 2014: impacts, adaptation, and vulnerability. Part A: global and sectoral aspects. Contribution of Working Group II to the Fifth Assessment Report of the Intergovernmental Panel on Climate Change. Cambridge University Press, Cambridge, UK.

Klenk, N. L. 2015. The development of assisted migration policy in Canada: an analysis of the politics of composing future forests. Land Use Policy 44:101-109. http://dx.doi.org/10.1016/j. landusepol.2014.12.003

Latta, G., H. Temesgen, D. Adams, and T. Barrett. 2010. Analysis of potential impacts of climate change on forests of the United States Pacific Northwest. Forest Ecology and Management 259 (4):720-729. http://dx.doi.org/10.1016/j.foreco.2009.09.003

Lawrence, A., and S. Gillett. 2011. Human dimensions of adaptive forest management and climate change: a review of international experience, a review of international experience. Forestry Commission, Edinburgh, UK.

Lawrence, A., and M. Marzano. 2014. Is the private forest sector adapting to climate change? A study of forest managers in north Wales. Annals of Forest Science 71(2):291-300. http://dx.doi. org/10.1007/s13595-013-0326-4

Leichenko, R., and K. O'Brien. 2006. Is it appropriate to identify winners and losers? Pages 97-114 in W. N. Adger, J. Paavola, S. Huq, and M. J. Mace, editors. Fairness in adaptation to climate change. MIT Press, Cambridge, Massachusetts, USA.

Leiserowitz, A., E. Maibach, and C. Roser-Renouf. 2009. Global warming's Six Americas. Yale Program on Climate Change Communication, Yale University, New Haven, Connecticut, USA.
McCaffrey, S., E. Toman, M. Stidham, and B. Shindler. 2012. Social science research related to wildfire management: an overview of recent findings and future research needs. International Journal of Wildland Fire 22(1):15-24. http://dx.doi. org/10.1071/WF11115

Miles, M. B., and A. M. Huberman. 1994. Qualitative data analysis. Sage, Thousand Oaks, California, USA.

Moser, S., and L. Dilling. 2004. Making climate hot: communicating the urgency and challenge of global climate change. Environment 46(10):32-46. http://dx.doi. org/10.1080/00139150409605820

Moser, S. C., and J. A. Ekstrom. 2010. A framework to diagnose barriers to climate change adaptation. Proceedings of the National Academy of Sciences 107(51):22026-22031. http://dx.doi. org/10.1073/pnas.1007887107

Nagel, L. M., B. J. Palik, M. A. Battaglia, A. W. D'Amato, J. M. Guldin, C. W. Swanston, M. K. Janowiak, M. P. Powers, L. A. Joyce, C. I. Millar, D. L. Peterson, L. M. Ganio, C. Kirschbaum, and M. R. Roske. 2017. Adaptive silviculture for climate change: a national experiment in manager-scientist partnerships to apply an adaptation framework. Journal of Forestry 115(3):167-178. http://dx.doi.org/10.5849/jof.16-039

National Oceanic and Atmospheric Administration (NOAA). 2017. U.S. climate divisions dataset nClimDiv. NOAA, Washington, D.C., USA. [online] URL: https://www.ncdc.noaa. gov/monitoring-references/maps/us-climate-divisions.php?section= grdd

Nicholas, K. A., and W. H. Durham. 2012. Farm-scale adaptation and vulnerability to environmental stresses: insights from winegrowing in Northern California. Global Environmental Change 22(2):483-494. http://dx.doi.org/10.1016/j.gloenvcha.2012.01.001

Ontl, T. A., C. Swanston, L. A. Brandt, P. R. Butler, A. W. D'Amato, S. D. Handler, M. K. Janowiak, and P. D. Shannon. 2018. Adaptation pathways: ecoregion and land ownership influences on climate adaptation decision-making in forest management. Climatic Change 146(1-2):75-88. http://dx.doi. org/10.1007/s10584-017-1983-3

Paton, D., M. Millar, and D. Johnston. 2001. Community resilience to volcanic hazard consequences. Natural Hazards 24 (2):157-169. http://dx.doi.org/10.1023/A:1011882106373

Patton, M. Q. 2002. Qualitative evaluation and research methods. Sage, Beverly Hills, California, USA.

Prichard, S. J., D. L. Peterson, and K. Jacobson. 2010. Fuel treatments reduce the severity of wildfire effects in dry mixed conifer forest, Washington, USA. Canadian Journal of Forest Research 40(8):1615-1626. http://dx.doi.org/10.1139/X10-109

Raymond, C. L., and D. L. Peterson. 2005. Fuel treatments alter the effects of wildfire in a mixed-evergreen forest, Oregon, USA. Canadian Journal of Forest Research 35(12):2981-2995. http://dx. doi.org/10.1139/x05-206

Raymond, C. M., and G. M. Robinson. 2013. Factors affecting rural landholders' adaptation to climate change: insights from 
formal institutions and communities of practice. Global Environmental Change 23(1):103-114. http://dx.doi.org/10.1016/ j.gloenvcha.2012.11.004

Ruseva, T. B., and B. C. Fischer. 2013. Public-private interactions in the conservation of private forests in the United States. HumanEnvironment Interactions 1:141-163. http://dx.doi. org/10.1007/978-94-007-4780-7 7

Schoene, D. H. F., and P. Y. Bernier. 2012. Adapting forestry and forests to climate change: a challenge to change the paradigm. Forest Policy and Economics 24:12-19. http://dx.doi.org/10.1016/ j.forpol.2011.04.007

Sheehan, T., D. Bachelet, and K. Ferschweiler. 2015. Projected major fire and vegetation changes in the Pacific Northwest of the conterminous United States under selected CMIP5 climate futures. Ecological Modelling 317:16-29. http://dx.doi.org/10.1016/ j.ecolmodel.2015.08.023

Slovic, P., M. L. Finucane, E. Peters, and D. G. MacGregor. 2007. The affect heuristic. European Journal of Operational Research 177(3):1333-1352. http://dx.doi.org/10.1016/j.ejor.2005.04.006

Smit, B., and J. Wandel. 2006. Adaptation, adaptive capacity and vulnerability. Global Environmental Change 16(3):282-292. http:// dx.doi.org/10.1016/i.gloenvcha.2006.03.008

Sousa-Silva, R., Q. Ponette, K. Verheyen, A. Van Herzele, and B. Muys. 2016. Adaptation of forest management to climate change as perceived by forest owners and managers in Belgium. Forest Ecosystems 3(1):22. http://dx.doi.org/10.1186/s40663-016-0082-7

Spies, T. A., T. W. Giesen, F. J. Swanson, J. F. Franklin, D. Lach, and K. N. Johnson. 2010. Climate change adaptation strategies for federal forests of the Pacific Northwest, USA: ecological, policy, and socio-economic perspectives. Landscape Ecology 25 (8):1185-1199. http://dx.doi.org/10.1007/s10980-010-9483-0

Spies, T. A., E. M. White, J. D. Kline, A. P. Fischer, A. Ager, J. Bailey, J. Bolte, J. Koch, E. Platt, C. S. Olsen, D. Jacobs, B. Shindler, M. M. Steen-Adams, and R. Hammer. 2014. Examining fire-prone forest landscapes as coupled human and natural systems. Ecology and Society 19(3):9. http://dx.doi.org/10.5751/ ES-06584-190309

Strauss, A., and J. Corbin. 1990. Basics of qualitative research: grounded theory procedures and techniques. Sage, Thousand Oaks, California, USA.

Strauss, A., and J. Corbin. 1994. Grounded theory methodology: an overview. Pages 273-285 in N. K. Denzin and Y. S. Lincoln, editors. Handbook of qualitative research. Sage, Thousand Oaks, California, USA.

Swanston, C. W., and M. Janowiak, editors. 2012. Forest adaptation resources: climate change tools and approaches for land managers. General Technical Report NRS-87. U.S. Forest Service, Northern Research Station, Newtown Square, Pennsylvania, USA. http://dx.doi.org/10.2737/NRS-GTR-87

Tompkins, E. L., and H. Eakin. 2012. Managing private and public adaptation to climate change. Global Environmental Change 22(1):3-11. http://dx.doi.org/10.1016/j.gloenvcha.2011.09.010
Turner, M. G. 2010. Disturbance and landscape dynamics in a changing world. Ecology 91:2833-2849. http://dx.doi. org/10.1890/10-0097.1

United Nations Economic Commission for Europe and Food and Agriculture Organization (UNECE FAO). 2010. Geneva timber and forest Study Paper 26: private forest ownership in Europe. UNECE FAO, Geneva, Switzerland.

van der Linden, S. 2015. The social-psychological determinants of climate change risk perceptions: towards a comprehensive model. Journal of Environmental Psychology 41:112-124. http:// dx.doi.org/10.1016/j.jenvp.2014.11.012

van Gameren, V., and E. Zaccai. 2015. Private forest owners facing climate change in Wallonia: adaptive capacity and practices. Environmental Science \& Policy 52:51-60. http://dx.doi. org/10.1016/j.envsci.2015.05.004

Vose, J. M., D. L. Peterson, and T. Patel-Weynand. 2012. Effects of climatic variability and change on forest ecosystems: a comprehensive science synthesis for the U.S. forest sector. General Technical Report PNW-GTR-870. U.S. Forest Service, Southern Research Station, Asheville, North Carolina, USA. http://dx.doi. org/10.2737/PNW-GTR-870

Vulturius, G., K. André, Å. G. Swartling, C. Brown, M. D. A. Rounsevell, and V. Blanco. 2018. The relative importance of subjective and structural factors for individual adaptation to climate change by forest owners in Sweden. Regional Environmental Change 18(2):511-520. http://dx.doi.org/10.1007/ $\underline{\mathrm{s} 10113-017-1218-1}$

Westerling, A. L. 2016. Increasing western U.S. forest wildfire activity: sensitivity to changes in the timing of spring. Philosophical Transactions of the Royal Society of London. Series B, Biological Sciences 371(1696):20150178. http://dx.doi. org/10.1098/rstb.2015.0178

Wimberly, M. C., M. A. Cochrane, A. D. Baer, and K. Pabst. 2009. Assessing fuel treatment effectiveness using satellite imagery and spatial statistics. Ecological Applications 19(6):1377-1384. http://dx.doi.org/10.1890/08-1685.1

Wise, R. M., I. Fazey, M. Stafford Smith, S. E. Park, H. C. Eakin, E. R. M. Archer Van Garderen, and B. Campbell. 2014. Reconceptualising adaptation to climate change as part of pathways of change and response. Global Environmental Change 28:325-336. http://dx.doi.org/10.1016/j.gloenvcha.2013.12.002

Yousefpour, R., A. L. D. Augustynczik, and M. Hanewinkel. 2017. Pertinence of reactive, active, and robust adaptation strategies in forest management under climate change. Annals of Forest Science 74(2):40. http://dx.doi.org/10.1007/s13595-017-0640-3 


\section{Appendix 1}

\section{Interview Guide}

\section{Respondent Information}

- Interview ID

- Date and time

- Latitude/longitude

- Community, County

- Sex

- Have you participated previously in a research survey or interview?

- Years lived in this county

- Years owned this property

- Are you a full-year or seasonal resident?

- Property

○ Did you inherit or buy your property?

- Total acres

- Forested acres

- Grazing acres

- Agricultural acres

○ Own other property in Oregon?

\section{Management Objectives, Plans and Actions}

1.0 What are your primary land management objectives?

2.0 Do you have a forest management (or stewardship) plan?

If yes:

2.0.1 How far into the future does it plan?

2.0.2 Does it include a forest inventory?

2.0.3 Did you prepare it, or get help?

2.0.4 If helped, by whom?

2.1 Overall would you say you plan forest management actions far in advance (how far)?

3.0 Which of the following management actions have you taken in the last 10 years?

Precommercial thinning, commercial thinning, ladder fuel removal, ground fuel removal, prescribed burns, forest pest management, timber sale, planting seedlings, slash pile burning, mastication/chipping, other (ask to describe)

3.1 How large of an area did you take these actions on?

3.2 Do you do management work yourself or hire a contractor (or both)?

3.3 Do you know what your reentry time is?

3.4 What are the different forest types on your property?

3.5 What actions, if any, do you have planned on your land in the next 5 years?

If yes: 3.5.1 At what scale? 
3.6 Do you actively manage to prevent or control noxious weeds?

4.0 Does the forest products market and economy overall affect your forestry activities?

If yes: 4.0.1 How?

4.1 Have public land management decisions affected you or your neighbors?

If yes: 4.1.1 How?

4.2 How well do you know the folks who own neighboring land?

4.3 Do you know if any of your neighbors have done/are doing active forest or grazing management?

\section{Perceptions of environmental change and adaptation actions}

5.0 What do you think makes a healthy forest?

5.1 Have you noticed any parts of your own forest or forest on neighboring land that looks unhealthy? If so, do you know why?

5.2 Do you take specific actions to reduce spread of pests and disease?

5.3 Are you concerned about any particular tree or shrub species on your land, either because of high mortality or because they're encroaching on certain areas?

5.4 Have you had any wildfires on your land or nearby?

If yes:

5.4.1 When did the fire(s) occur?

5.4.2 How large were they and how long did they burn?

5.5 Do you think your forests are at risk of wildfire? How great do you feel the risk of wildfire is on your property?

5.6 Do you take any specific actions to lower the risk of wildfire on your land?

5.7 Has the threat of wildfire changed in any way since you first moved here?

5.8 Do any of your management decisions involve planning for changes in wildfire threat in the future?

5.9 Are you worried about wildfire or insects/disease spreading from neighboring land to your property?

6.0 (If grazing): Have you experienced any challenges getting enough good water for the cattle? If yes: 6.0.1 When did you have these difficulties, and what did you do?

6.1 (If grazing/agriculture): Have you experienced any problems with drought affecting your forage/crops?

If yes: 6.1.1 When did you have these difficulties, and what did you do?

6.2 (If not grazing/no agriculture): Have you had any problems associated with drought since you've lived here?

6.3 Are your reservoirs, wells or ponds different levels than in the past?

If yes: 6.3.1 When? What did you do?

6.4 Are you concerned about decreased water availability in the future? 
If yes: 6.4.1 Why?

6.5 Are you at all concerned about the effects of your neighbors on your water supply or water quality?

If yes: 6.5.1 Why?

6.6 Have you had any problems with flooding since you lived here?

If yes: 6.5.1 When? What did you do?

6.7 Have you noticed more or less snow over the years, or snow melting at different times since you've lived here?

If yes: 6.7.1 Is this a concern for you?

7.0 Have you noticed any changes in temperature in this region since you've lived here?

If yes: 7.1.1 Is this a concern for you?

\section{Beliefs and attitudes regarding climate change}

8.0 Do you think that climate change is happening? Why or why not?

8.1 Do you think climate change is affecting temperatures, precipitation, drought, or insects and disease on your property? Overall in eastern Oregon?

If yes: 8.1.1 Do you think this will become a bigger management challenge in the future? Why or why not?

\section{Engagement and Resource Needs}

9.0 Have you participated in any activities with OSU Extension Service, stewardship organizations or forest collaboratives in the last 5 years, like workshops or meetings?

If yes: 9.0.1 How often do you participate?

9.1 If you had a question about your forest who would you call?

9.2 Do you get any regular newsletters from forest management or agriculture groups?

9.3 Do you need any additional resources to manage your land differently or better than the way you do now?

9.4 Are there any other issues you'd like to talk about?

9.5 Do you know anyone else who might be interested in participating in this research?

\section{Demographic Information}

- Age

- Current occupation

- Past occupation

- Highest education level attained

- Do you plan to leave this in the next 5 years?

- Do you know if you will eventually sell your land or pass it on to someone?

- In terms of your political views, do you consider yourself a Republican, Democrat, or Independent? If Republican, do you support the Tea Party? 
CODEBOOK: Climate Adaptation and Non-industrial Private Forest Owners in Eastern Oregon

\section{Codes corresponding to outcomes:}

ACTNS - forest management actions taken in last 10 years

- $\quad$ PCT - Pre-commercial thinning

- $\mathrm{CT}$ - commercial thinning

- TIMSALE - timber sale

- GRNDR - ground fuel removal

- LADR - ladder fuel removal

- PLBURN - slash pile burning

- $\quad$ CHPNG - chipping slash and spreading/taking away

- INDTR - removal of individual dead/diseased/infested trees

- RXBRN - prescribed burn

- REFOR - reforestation: planting seedlings either to supplement natural regeneration or as restoration following wildfire/logging

EXTNT - extent of active management on property

- WHLPROP - whole property

- PROPSECT - large section of property

- STAND - stand-level active management

- INDTRL - individual tree-level management

PLNACTNS - planned future actions

- NOACT - no actions

- MAINT - maintain outcome of past treatments

- CONT - continue past treatment actions elsewhere on property/re-enter same location at a later date

FMP - have a forest management plan

- HQFMP - high quality FMP written within last 10 years with forest inventory

- LQFMP - low quality FMP, either outdated or partial (missing forest inventory)

- INFMP - informal FMP - either "in my head" or otherwise not formalized

- NOFMP - no forest management plan

PLNHORZN - planning horizon

- 30PLUS - plan more than 30 years into the future

- $20 \mathrm{TO} 30$ - plan twenty to thirty years into the future

- $10 \mathrm{TO} 20$ - plan ten to twenty years into the future 
- $0 \mathrm{TO} 10$ - plan zero to ten years into the future

- OPP - take action spontaneously as opportunity arises

\section{ADPTN}

- IMPADPT - implemented climate change adaptation action

- SUGG - adaptation action suggestion/intention

- INTADPT - implemented/suggested adaptation is climate change-motivated (intentional)

- INCADPT - implemented/suggested adaptation is not climate change-motivated (incidental)

- CCIMPF - may consider adaptation options in the future when climate change impacts appear

- TIMBD - concerns about maintaining timber density while also keeping trees healthy

- NOCHG - would not change forest management practices regardless of climate change

\section{Codes corresponding to subjective barriers to adaptation:}

BELV - belief in anthropogenic climate change

- $\mathrm{NOCC}$ - there is no climate change occurring

- DKBEL - do not know what they believe/cannot say

- BELVDK - believe it is happening but do not know why

- NATCY - it is a natural cycle

- ANTHR - it is anthropogenic climate change

- ANTHNAT - it is a combination of natural cycles and anthropogenic climate change

PRCV - perceives/experiences local climate changes

- $\mathrm{WRMG}$ - perceives warming locally

- DRYG - perceives more frequent drought

- LOSNW - lower snowpack in recent years

FIRERSK - self-assessed risk of wildfire on own property

- NORSK - not at risk of wildfire

- LORSK - low risk of wildfire

- MEDRSK - medium risk of wildfire

- HIRSK - high risk of wildfire

INCRSK

- YINDRGHT - yes, wildfire risk is increasing because of drought

- YINSUPFAIL - yes, wildfire risk is increasing because of fire suppression failure

- YINC - yes, wildfire risk is increasing but I am not sure why 
- $\quad$ NOINC - no, wildfire risk is not increasing

CCIMP - ways in which climate change will impact forests in eastern Oregon

- INFDEF - information deficit/uncertainty; climate change is happening but cannot predict what local impacts will be

- DRTSTRSS - will cause drought stress

- INCBUGS - anticipate more insect and disease issues

- INCFIRE - anticipate more large wildfires in future

- SPP - may change which species can live where

\section{Codes corresponding to structural barriers to adaptation:}

\section{TIMBMRKT}

- NOTIMR - timber markets do not impact management

- MILLSHT - Mill shutdowns have increased hauling costs or otherwise raised costs (e.g., no competition between mills so log prices are lower)

- HAULCSTS - haul costs impact management (e.g. high price of diesel, high pay for truckers)

- LOGPRIC - $\log$ prices too low

- MINVOL - forest owners has too little volume to sell to a mill

- NOMRKSMD - no market for small diameter timber

RSRCNEEDS - resource needs

- MONEY - need money for adaptive management (e.g. grants, cost-shares etc.)

- TIME - need more time to do management

- EQUIPMENT - need new/different equipment (e.g. to rent, hire or grants for buying)

- LABOR - need assistance performing actions

- EDUCATION - need more/different education on management strategies

- BETTERMRKTS - need better log markets to provide economic incentives for management

- $\mathrm{TOPO}$ - topography is too challenging to treat

NETWRK - organizations/networks individual engages with to gain resources

- OSUEXT - OSU Extension

- ODF - Oregon Department of Forestry

- PERSEXP - Personal experience (self or close family/friend)

- NRCS - Natural Resource Conservation Service

- OSWA - Oregon Soil and Water Association 